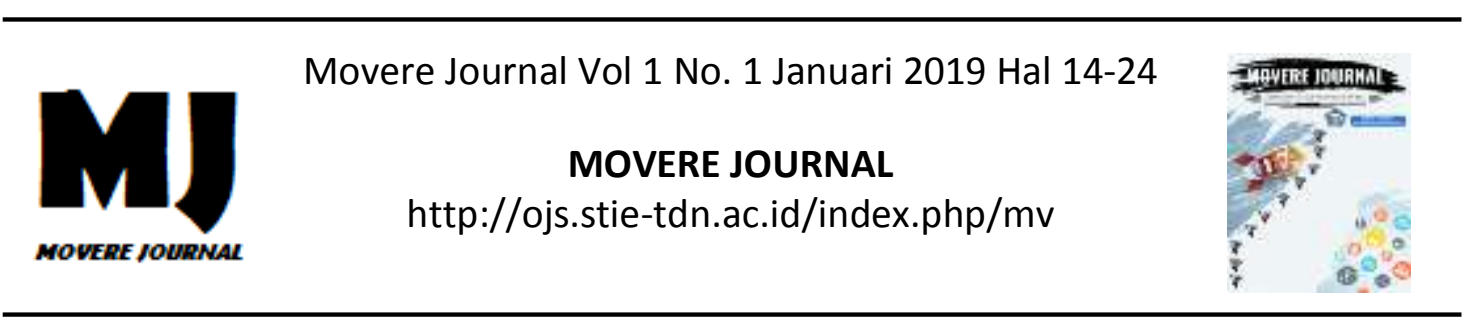

\title{
PENGARUH BIAYA PROMOSI TERHADAP PENINGKATAN VOLUME PENJUALAN PRODUK WIKA AIRCON WEATER HEATER (AWH) PADA PT. SURYA PUZULINDO MAKASSAR
}

\author{
Karta Negara Salam \\ STIM Nitro Makassar
}

\begin{abstract}
Abstrak: Penelitian ini bertujuan untuk mengukur pengaruh biaya promosi terhadap peningkatan volume penjualan produk Wika Aircon Weater Heater (AWH) pada PT Surya Puzulindo Makassar. Adapun variabel bebas dalam penelitian ini adalah biaya Promosi dan variabel terikat adalah Volume Penjualan.Merupakan penelitian kuantitatif dengan menggunakan metode analisis deskriptif dan analisis regresi sederhana. Jenis data terdiri dari data kualitatif dan data kuantitatif, dimana metode pengumpulan data terdiri dari observasi, wawancara, dan dokumentasi.Hasil penelitian ini menunjukkan bahwa biaya promosi berpengaruh positif dan signifikan terhadap peningkatan volume penjualan produk Wika Aircon Weater Heater (AWH) pada PT Surya Puzulindo Makassar.Dari penelitian ini terbukti bahwa dengan memperhatikan biaya promosi yang ditawarkan dan dibarengi dengan kualitas produk dan pelayanan yang baik maka dapat meningkatkan minat pelanggan terhadap produk yang dipasarkan. Besarnya kontribusi dari biaya promosi terhadap peningkatan volume penjualan produk Wika Aircon Weater Heater (AWH) adalah 99,4\%.
\end{abstract}

Kata kunci : pemasaran, bauran promosi, biaya promosi, dan volume penjualan

\section{PENDAHULUAN}

Banyaknya perusahaan yang bermunculan melahirkan persaingan yang tajam diantara perusahaanperusahaan yang sejenis. Sehingga untuk mempertahankan kelangsungan hidup perusahaan, mereka sering dihadapkan pada berbagai masalah seperti kesulitan dalam peningkatan penjualan, adanya persaingan yang cukup ketat dari berbagai perusahaan yang sejenis, kompleksnya perilaku konsumen terhadap suatu produk terutama selera pada pemuasan kebutuhan dan keinginan konsumen yang selalu berubah-ubah, serta kondisi perekonomian itu sendiri.

Untuk dapat mengantisipasi berbagai permasalahan yang tejadi khususnya dibidang pemasaran dewasa ini, diperlukan adanya perubahan sistem pemasaran kearah yang lebih efektif. Pemasaran yang efektif dalam penerapannya bukan hanya dengan meningkatkan penjualan, tapi dibarengi dengan mengamati tingkah laku para pesaing serta keinginan konsumen dengan berdasarkan pada perbaikan kualitas, tempat yang mudah dijangkau, jumlah produk yang sesuai dipasaran, dan harga yang terjangkau oleh konsumen. Untuk itu diperlukan suatu strategi dalam bidang pemasaran khususnya strategi dan biaya promosi. Tanpa adanya promosi yang efektif, maka yakinlan produk tersebut tidak akan dikenal oleh konsumen. Untuk itu seorang iklanajer dituntut untuk mendesain suatu promosi barang dan jasa yang diproduksikan atau dihasilkan oleh perusahaan yang dipimpinnya. 
Demikian halnya PT Surya Puzulindo Makassar sebagai salah satu distributor tunggal, tentulah membutuhkan strategi dalam mempromosikan produknya yang bertujuan untuk merangsang minat beli konsumen terhadap produk yang dihasilkan, serta dapat meningkatkan penjualan, minimal mampu mempertahankannya. Kegiatan promosi yang dilakukan ini harus sejalan dengan rencana pemasaran secara keseluruhan serta direncanakan, diarahkan, dan dikendalikan dengan baik sehingga dapat berperan dalam meningkatkan volume penjualan.

PT. Surya Puzulindo merupakan perusahaan yang bergerak dalam bidang penjualan produk Wika Aircon Weater Heater (selanjutnya disingkat AWH). Didalam mengantisipasi meningkatnya persaingan dan untuk dapat meningkatkan volume penjualan produknya, maka PT. Surya Puzulindo dalam memasarkan produk-produknya tersebut harus melancarkan promosi yang lebih agresif, tepat dan berusaha memperhitungkan biaya promosi yang dikeluarkan guna meningkatkan volume produk penjualan sehingga dapat memperoleh keuntungan dari tahun ke tahun.

\section{Pemasaran}

Pemasaran memiliki cakupan kegiatan yang lebih luas yang meliputi perumusan jenis produk yang diinginkan oleh konsumen, perhitungan beberapa banyak kebutuhan akan produk itu, cara menyalurkan produk kepada konsumen, serta mengatasi kondisi persaingan yang dihadapi oleh perusahaan dan sebagainya. Oleh karena itu perusahaan harus mampu untuk menjalin hubungan akrab antara perusahaan harus mampu untuk menjalin hubungan yang akrab antara perusahaannya dengan masyarakat yang menjadi konsumen bagi produk-produk yang dihasilkan dan dipasarkan. Hubungan yang baik antara perusahaan dengan konsumennya akan mendatangkan keuntungan bagi kedua belah pihak.

Menurut Kotler (2000:9) memberikan definisi pemasaran dari segi sosial yang sesuai dengan tujuan, sebagai berikut :

"Pemasaran adalah suatu proses sosial yang didalamnya individu dan kelompok mendapatkan apa yang mereka butuhkan dan inginkan dengan menciptakan, menawarkan, dan secara bebas mempertukarkan produk yang bernilai dengan pihak lain."

Pemasaran terdiri dari serangkaian prinsip untuk memilih sasaran pasar (target market), mengevaluasi kebutuhan konsumen, mengembangkan barang dan jasa pemuas keinginan. Memberikan nilai kepada konsumen dan laba bagi perusahaan. Maka tidaklah mengherankan jika hampir semua perusahaan manufaktur maupun jasa/konsultan menerapkan rencanarencana pemasaran masing-masing.

Menurut Assauri (2004:19) kegiatan pemasaran dapat diklasifikasikan kedalam tiga bidang kegiatan, yaitu (1) Kegiatan transaksi atau transfer, meliputi pembelian (buying) dan penjualan (selling), (2) Kegiatan suplai fisik, yang meliputi pengangkutan (transportation) dapergudangan/penyimpanan (storage), (3) Kegiatan penjualan untuk memperlancar arus kegiatan transaksi dan arus barang, yang meliputi penjajahan (merchandising), standarnisasi dan grading, pembelanjaan (financing), penangungan risiko (risk taking), informasi pasar (market information). Hubungan yang baik antara perusahaan dengan konsumennya akan mendatangkan keuntungan bagi kedua belah pihak. Masyarakat yang menggunakan barang hasil produksi perusahaan itu akan memperoleh keuntungan dalam bentuk mendapatkan barang sebagai pemenuhan 
kebutuhannya dengan kualitas yang baik, sedangkan perusahaan memperoleh keuntungan dalam bentuk diperolehnya penghasilan untuk membiayai kegiatankegiatan perusahaan tersebut. Proses pemasaran merupakan kegiatan yang berupa penentuan jenis produk yang dihasilkan, jumlah yang harus dipasarkan, harga yang ditetapkannya, cara penyalurannya, bentuk promosinya, dan sebagainya.

\section{Bauran Promosi}

Kegiatan pemasaran pada masa sekarang ini tidak cukup hanya dengan pengembangan produk, peningkatan kualitas, penetapan harga yang terjangkau atausaluran produk yang tepat, akan tetapi produsen harus dapat berkomunikasi dengan konsumennya. Perusahaan harus melakukan salah satu variabel dari marketing mix, yaitu promosi.

Menurut Fuad (2005;103) "Promosi merupakan salah satu variabel bauran pemasaran yang digunakan oleh perusahaan untuk mengadakan komunikasi dengan pasarnya. Promosi juga sering dikatakan sebagai proses berlanjut karena dapat menimbulkan rangkaian kegiatan selanjutnya dari perusahaan".

Sedangkanmenurut

Kotler $(2000 ; 87)$ mendefinisikan promosi sebagai berikut.

"Promosi adalah salah satu bagian terpenting dalam kegiatan pemasaran dan sangat menentukan dalam pencapaian tujuan perusahaan.Oleh karena itu dalam usaha untuk mencapai tujuan tersebut maka perusahaan harus mencari bentuk promosi yang paling efektif dan kombinasi terbaik dari bentuk-bentuk promosi yang ada sesuai dengan tujuan sasaran pasar".

Ada beberapa faktor yang menyebabkan suatu perusahaan atau suatu organisasi memerlukan kegiatan promosi, yaitu :

1. Jarak antara produsen dan konsumen yang cukup jauh serta jumlah potensial pelanggan yang semakin meningkat sehingga masalah komunikasi pasar menjadi sangat penting.

2. Adanya persaingan yang cukup tajam antara berbagai jenis industri dan antar perusahaan dalam satu cabang industri.

3. Jika tiba masa kekurangan (resesi), maka masalah kunci terletak pada masalah penjualan.

Adapun tujuan melakukan

promosi, yaitu:

1. Modifikasi tingkah laku, yaitu penjual berusaha menciptakan kesan baik tentangdirinya atau mendorong pembelian barang dan jasa yang dihasilkan melaluipromosi sebagai alat untuk mempengaruhi pembeli.

2. Memberitahu, yaitu kegiatan promosi yang ditujukan untuk memberitahukan pada konsumen tentang penawaran yang dilakukan oleh perusahaan.

3. Membujuk, yaitu diharapkan dengan promosi ini hasil penjualan perusahaan akan meningkat dengan terlebih dahulu membujuk konsumen agar dapat membeli barang atau jasa yang dihasilkan perusahaan.

4. Mengingatkan dilakukan terutama untuk mempertahankan merek produk di dalam hati konsumen dan perlu dilakukan selama tahap kedewasaan di dalam siklus kehidupan produk, agar perusahaan dapat mempertahankan pelanggan yang ada.

Menurut Swastha $(2001 ; 102)$ "Bauran promosi adalah kombinasi strategi yang paling baik dari variabelvariabel periklanan, personal selling, dan alat promosi yang lain, yang seluruhnya direncanakan untuk mencapai tujuan programpenjualan".

Mengukur efektifnya suatu 
kegiatan promositerutama periklanan sangat sulit.Evaluasi terhadap kinerja promosi hanya berdasarkan tingkat penjualan suatumetode yang sangat sederhana dan tidak mampu meng-cover bahwa kegiatan tersebut telah berhasil meningkatkan volume penjualan sebab hal ini tidak lepas dari kegiatan bauran pemasaran yang ditetapkan.

Jadi untuk mengevaluasi kegiatan promosi perlu dilakukan secara lebih serius dan lebih khusus dalam metode dan media promosi yang digunakan. Salah satu yang dapat dilakukan adalah pengukuran terhadap efektivitas periklanan dengan melakukan riset dan pengujian terhadap muatan iklan dan reaksi konsumen terhadap iklan tersebut.

\section{Biaya Promosi}

Penjualan merupakan hal pokok bagi kesehatan dan kesejahteraan, tujuan semua usaha pemasaran adalah menambah penjualan yang menguntungkan dengan menawarkan pemenuhan kebutuhan dalam jangka panjang. Perbedaan antara konsep penjualan dan pemasaran adalah pada konsep penjualan lebih memasarkan pada kebutuhan penjualan, sedangkan konsep pemasaran memusatkan perhatian pada kebutuhan pembeli. Konsep penjualan dipenuhi dengan masalah mengubah penjualan menjadi uang, konsep pemasaran dipenuhi oleh gagasan untuk memuaskan kebutuhan pembeli dengan memanfaatkan produk dan seluruh gugus produk yang berkaitan dengan penciptaan, penyerahan, dan akhirnya pemakaian produk itu.

Perusahaan dapat dipandang sebagai suatu sistem yang memproses masukan untuk menghasilkan keluaran. Perusahaan yang bertujuan mencari laba maupun yang tidak bertujuan mencari laba mengelola masukan berupa sumber ekonomi untuk menghasilkan keluaran berupa sumber ekonomi lain yang nilainya harus lebih tinggi dari nilai masukannya. Oleh karena itu, baik dalam usaha yang bermotif laba maupun yang tidak bermotif laba. Manajemen selalu berusaha agar nilai keluaran lebih tingi dari nilai masukan yang dikorbankan untuk menghasilkan keluaran tesebut, sehingga kegiatan organisasi dapat menghasilkan laba (untuk perusahaan bermotif laba) atau sisa hasil usaha (untuk perusahaan yang tidak bermotif laba).

Dengan laba atau sisa hasil usaha tersebut, perusahaan akan memiliki kemampuan untuk berkembang dan tetap mampu mempertahankan eksistensinya sebagai suatu sistem dimasa yang akan datang. Dengan demikian untuk menjamin bahwa suatu sistem kegiatan usaha menghasilkan keluaran lebih tinggi dari pada nilai masukan, diperlukan alat untuk mengukur nilai masukan yang dikorbankan untuk menghasilkan keluaran yang diharapkan.

\section{METODE PENELITIAN}

\section{Lokasi dan Waktu Penelitian}

$$
\text { Adapun lokasi penelitian }
$$
dilakukan di PT Surya Puzulindo Makassar dengan estimasi waktu penelitian kurang lebih dua bulan terhitung mulai Bulan Maret sampai dengan Bulan April 2012.

\section{Metode Pengumpulan Data}

Adapun metode pengumpulan data yang dilakukan dalam penelitian ini adalah (1) Observasi, yaitu penelitian yang dilakukan dengan mengadakan pengamatan terhadap objek penelitian guna memperoleh bahan dan data-data yang diperlukan, (2) Wawancara, yaitu melakukan tanya jawab dengan pihak perusahaan PT. Surya Puzulindo Makassar yang berhubungan erat dengan bidang pemasaran, dan (3) Dokumentasi, yaitu kegiatan yang dilakukan dengan menelaah buku bacaan atau literatur, serta karya ilmiah yang erat hubungannya masalah pokok penelitian. 
Jenis dan Sumber Data

Adapun jenis data pada penelitian ini adalah (1) Data Kualitatif adalah data yang diperoleh dalam bentuk informasi baik secara lisan maupun tulisan yang antara lain berupa sejarah perusahaan dan penjelasan lain yang diperlukan dalam penulisan, dan (2) Data Kuantitatif adalah data yang diperoleh dalam bentuk angka yang dapat dihitung, meliputi penjualan dan biaya-biaya promosi yang berhubungan dengan masalah yang dibahas.

Sedangkan sumber data pada penelitian ini adalah (1) Data Primer merupakan data yang diperoleh penulis dari objek penelitian berdasarkan observai dan wawancara dengan pimpinan dan karyawan, dan (2) Data Sekunder merupakan data yang diperoleh penulis dari objek penelitian berupa dokumentasi atau laporan tertulis dari perusahaan.

\section{Metode Analisis}

Sedangkan metode analisis yang digunakan dalam penelitian ini, adalah (1) Analisis deskriptif yaitu untuk mengetahui seberapa besar biaya promosi yang dikeluarkan oleh PT Surya Puzulindo Makassar dalam meningkatkan volume penjualan produk Wika AWH, dan (2) Analisis regresi sederhana yaitu analisis yang dilakukan melalui perhitungan angka-angka untuk menghitung dan mengestimasi seberapa besar pengaruh biaya promosi yang dikeluarkan oleh PT Surya Puzulindo Makassar terhadap peningkatan volume penjualan produk Wika AWH.

\section{HASIL PENELITIAN DAN PEMBAHASAN}

\section{Kegiatan Promosi Produk Aircone Water Heater (AWH) pada PT Surya Puzulindo Makassar}

Untuk menunjang tercapainya tujuan tersebut maka PT Surya Puzulindo Makassar perlu mengupayakan penerapan baruan pemasaran terutama promosi sebab peranan bauran pemasaran sangat signifikasn dalam meningkatkan volume penjualan. Promosi dilaksanakan dengan tujuan memberikan informasi tentang produk, membujuk dan mengingatkan. Selain kegiatan promosi yang secara umum dilakukan oleh suatu perusahaan PT Surya Puzulindo Makassar dalam mempromosikan Produk Aircon Water Heater (AWH) haruslah disertakan dengan berbagai keuntungan baik pada pelanggan maupun pada perusahaan itu sendiri.

Produk Wika Aircon Water Heater (AWH) diproduksi dengan standar mutu tinggi dan menerapkan sistem manajemen mutu ISO 9001-2000, menjadikan Wika AWH menjadi produk pemanas air yang paling terpercaya dan mendapat pengakuan internasional. Keunggulan mutu dan daya tahan produk Wika AWH terhadap cuaca serta layanan purna jual yang tersebar diberbagai kota di Indonesia menjadikan Wika AWH sebagai pemanas air energi matahari yang paling banyak dipakai di Indonesia.

Adapun sasaran yang ingin dicapai oleh pihak manajemen PT Surya Puzulindo Makassar dalam kegiatan promosinya adalah :

1. Mengubah image yang berkembang di masyarakat tentang kualitas produk Wika AWH.

2. Memberikan pengenalan dan pengetahuan terhadap pemakaian produk Wika AWH tentang cara penggunaan terbaik produk Wika AWH.

3. Meyakinkan konsumen mengenai kualitas dan pelayanan produk Wika AWH tidak kalah dengan produk lain.

4. Dapat meningkatkan atau mendongkrak volume penjualan.

Adapun bauran promosi yang dilaksanakan oleh pihak manajemen PT Surya Puzulindo, yaitu :

1. Periklanan (Advertising), dimana jenis periklanan yang dilakukan PT 
Surya Puzulindo Makassar menggunakan (1) media cetak yang mengetengahkan keunggulan dan reportasi dari produk yang dihasilkan, (2) media massa berupa radio swasta yang juga memberikan keunggulankeunggulan yang dimiliki serta menyajikan kemudahan-kemudahan untuk memperoleh produk tersebut, (3) memasang papan reklame yang dipasang di jalan-jalan strategis untuk menarik perhatian masyarakat khususnya calon konsumen.

2. Promosi penjualan, dimana kegiatan ini untuk mempengaruhi konsumen secara langsung sehingga dapat menimbulkan minat masyarakat untuk membeli produk yang ditawarkan setelah melihat sendiri produk tersebut. Promosi penjualan juga merupakan kegiatan promosi yang dilakukan dengan mengadakan pameran, peragaan atau demosntrasi dan berbagai kegiatan lain yang dilakukan sewaktu-waktu dan bersifat rutin.

\section{Analisis Perkembangan Biaya Promosi dan Tingkat Penjualan Produk Wika AWH pada PT. Surya Puzulindo Makassar}

Analisis Perkembangan Biaya

Kegiatan promosi PT Surya Puzulindo Makassar dilaksanakan melalui periklanan, pemanfaatan personal selling, dan menetapkan harga produk yang bersaing di seluruh segmentasi pasar.Dalam merealisasikan program periklanan, perusahaan cenderung memilih saluran informasi yang lebih efesien dan lebih berdaya guna bagi peningkatan penjualan.

Salah satu faktor yang perlu menjadi pertimbangan dalam memilih media promosi adalah anggaran atau besar kecilnya dana yang tersedia untuk kegiatan promosi selam satu priode waktu tertentu.Semakin terbatasnya anggaran yang disediakan akan mengakibatkan semakin sempit pula ruang gerak perusahaan dalam kesempatannya memilih media promosi. Sebaiknya, tersedianya anggaran biaya yang memadai akan semakin leluasa perusahaan untuk memilih media atau promosi yang dianggap paling menguntungkan.

Berikut ini daftar pengeluaran yang dilakukan oleh perusahaan dalam membiayai kegiatan produksi, yaitu :

Tabel 5.1

Perkembangan Biaya Promosi Produk Wika AWH (Dalam jutaan) pada PT Surya Puzulindo Makassar

Periode Tahun 2004-2008

\begin{tabular}{lccc}
\hline Tahun & Biaya Promosi & \multicolumn{2}{c}{ Perkembangan } \\
\hline & Wika AWH $(\mathbf{R p})$ & $\mathbf{( R p )}$ & $\mathbf{( \% )}$ \\
\hline 2004 & $3,350,000$ & - & - \\
2005 & $3,850,000$ & 500,000 & 0.15 \\
2006 & $4,450,000$ & 600,000 & 0.16 \\
2007 & $5,200,000$ & 750,000 & 0.17 \\
2008 & $6,150,000$ & 750,000 & 0.18 \\
Rata-rata & $\mathbf{4 , 6 0 0 , 0 0 0}$ & $\mathbf{7 0 0 , 0 0 0}$ & $\mathbf{0 . 1 6}$ \\
\hline Sumber : PT Surya Puzulindo Makassar, tahun 2009
\end{tabular}

Sumber : PT Surya Puzulindo Makassar, tahun 2009

Dari tabel perkembangan biaya promosi diatas dapat dilihat bahwa perusahaan meningkat dari tahun ke tahun. Pada tahun 2005 biaya produksi 
yang dikeluarkan oleh PT Surya Puzulindo Makassar adalah sebesar Rp. 3.850.000, berarti terjadi kenaikan sebesar Rp. 500.000 atau sekitar 0,15\% dari tahun 2004. Pada tahun 2006 biaya produksi sebesar Rp. 4.450 .000 mengalami peningkatan sebesar Rp. 600.000 atau $0,16 \%$, kemudian meningkat kembali pada tahun 2007 sebesar Rp. 750.000 atau sekitar 0,17\%. Besarnya jumlah biaya promosi yang dikeluarkan oleh perusahaan adalah karena adanya peningkatan kuantitas dan kualitas dari kegiatan promosi yang dikeluarkan sebelumnya.Sedangkan pada tahun 2008 biaya promosi kembali bertambah yaitu sebesar Rp. 6.150 .000 terjadi peningkatan sebesar Rp. 950.000 atau sekitar $0,18 \%$, peningkatan biaya promosi ini dilakukan untuk menambah jumlah konsumen produk Wika AWH. Adapun rata-rata perkembangan biaya promosi setiap tahun adalah sebesar Rp. 700.000 atau sekitar $0,16 \%$.

\section{Tingkat Penjualan Produk Aircon Water Heater (AWH)}

Dalam menjalankan operasional usahanya, PT Surya Puzulindo Makassar akan berhadapan langsung dengan konsumen pada suatu ruang lingkup pasar, dimana distributor produk lainnya turut menjadi pesaing sekaligus menjadi kendala. Meskipun demikian, PT Surya Puzulindo Makassar telah menyiapkan langkah-langkah antisipatif berupa suatu program secara terpadu yang direalisasikan dalam beberapa bentuk kegiatan antara lain menginformasikan keadaan dan kualitas produk melalui promosi, memperbaiki mutu pelayanan, memberikan garansi pelayanan servis sampai waktu tertentu, memberikan berbagai keunggulan dan kemudahan dalam menggunaka produk Wika AWH dan memanfaatkan keberadaan tenaga pemasaran secara maksimal untuk mengarahkan keputusan konsumen untuk membeli. Manajemen perusahaan yang diterapkan perusahaan sebagai antisipasi, memang belum dapat mengoptimalkan pencapaian tujuan penjualan perusahaan, namun telah memberikan kontribusi terhadap penjualan produk Wika AWH setiap tahunnya.

Untuk melihat sejauh mana perkembangan dalam penjualan produk Wika AWH disajikan jumlah penjualan tahun 2004-2008 seperti terlihat dalam tabel berikut ini:

Tabel 5.2

Jumlah Penjualan Produk Wika AWH

Pada PT. Surya Puzulindo Makassar

Periode Tahun 2004-2008

\begin{tabular}{lccc}
\hline Tahun & $\begin{array}{c}\text { Produk Wika } \\
\text { AWH }\end{array}$ & \multicolumn{2}{c}{ Perkembangan } \\
$(\mathbf{R p})$ & $(\boldsymbol{\%})$ \\
\hline 2004 & 200 & - & - \\
2005 & 255 & 55 & $28 \%$ \\
2006 & 310 & 55 & $22 \%$ \\
2007 & 392 & 82 & $26 \%$ \\
2008 & 450 & 58 & $15 \%$ \\
Rata-rata & $\mathbf{4 , 6 0 0 , 0 0 0}$ & $\mathbf{6 3}$ & $\mathbf{2 3 \%}$ \\
\hline
\end{tabular}

Sumber : PT Surya Puzulindo Makassar, tahun 2009

(C) 2019 STIE TDN. All rights reserved

Corresponding Author: kartanegara@ nitromks.ac.id 
Dapat dilihat bahwa jumlah produk Wika AHW pada PT Surya Puzulindo Makassar dari tahun ke tahun mengalami peningkatan meskipun dari perkembangan jumlah produk mengalami fluktuasi, dimana pada tahun 2005 jumlah produk sebesar 255 meningkat sebesar 55 unit atau sekitar 28\% dari tahun 2004, pada tahun 2006 jumlah produk Wika AHW sebanyak 310 unit meningkat sebesar $22 \%$ dari tahun 2005, sedangkan pada tahun 2007 jumlah produk Wika AHW mengalami peningkatan dari 310 unit menjadi 392 meningkat sebesar $28 \%$ atau 26\%, kembali terjadi peningkatan pada tahun 2008 yakni dari 392 unit menjadi 450 unit, meskipun dari jumlah perkembangan produk Wika AHW mengalami penurunan yaitu 82 menjadi 58 atau sekitar $15 \%$. Tetapi secara ratarata meningkat sekitar $32 \%$ per tahun dengan jumlah produk Wika AHW ratarata sebanyak 663 unit per tahun.

Sedangkan untuk melihat sejauh mana perkembangan volume penjualan produk Wika AHW tahun 2004-2008 dapat dilihat berikut ini :

Tabel 5.3

Jumlah Volume Penjualan Produk Wika AWH

Pada PT. Surya Puzulindo Makassar

Periode 2004-2008

\begin{tabular}{lcccc}
\hline Tahun & $\begin{array}{c}\text { Produk Wika } \\
\text { AWH (unit) }\end{array}$ & $\begin{array}{c}\text { Harga Produk } \\
\text { Wika AWH (Rp) }\end{array}$ & $\begin{array}{c}\text { Jumlah Volume } \\
\text { Penjualan Produk } \\
\text { Wika AWH(Rp) }\end{array}$ & $\begin{array}{c}\text { Persentase } \\
(\mathbf{\%})\end{array}$ \\
\hline 2004 & 200 & $7,720,000$ & $1,544,000,000$ & - \\
2005 & 255 & $7,920,000$ & $2,019,600,000$ & $31 \%$ \\
2006 & 310 & $8,330,000$ & $2,582,000,000$ & $28 \%$ \\
2007 & 392 & $8,720,000$ & $3,411,500,000$ & $32 \%$ \\
2008 & 450 & $9,150,000$ & $4,117,500,000$ & $20 \%$ \\
Rata-rata & $\mathbf{3 2 1} \mathbf{8 , 3 6 8 , 0 0 0}$ & $\mathbf{2 , 7 3 6 , 3 2 8 , 0 0 0}$ & $\mathbf{2 8 \%}$ & \\
\hline
\end{tabular}

Sumber : PT. Surya Puzulindo Makassar, tahun 2009

Pada tabel diatas menunjukkan terjadinya peningkatan tingkat volume penjualan produk Wika AWH selama periode 5 tahun dari periode 2004-2008, baik dilihat dari jumlah unit maupun jumah rupiah. Pada tahun 2005 penjualan produk Wika AWH sebesar 255 unit atau Rp. 2.019.600.000 meningkat $31 \%$ dari tahun 2004, meningkat menjadi 310 unit dengan tingkat volume penjualan sebesar $\mathrm{Rp}$. 2.582.300.000 atau sekitar $28 \%$ dai tahun 2006, pada tahun 2007 meningkat menjadi 392 unit atau sebesar Rp 3.418.240.000 atau sekitar $32 \%$ dari tahun 2006.
Selanjutnya pada tahun 2008 tingkat penjualan produk Wika AWH kembali mengalami peningkatan menjadi 450 unit dengan volume penjualan sebesar Rp. 4.117.500.000 atau sekitar 20\%.

Dengan demikian tingkat volume penjualan pada PT Surya Puzulindo Makassar selama periode tahun 20042008 atau selama 5 tahun secara rata-rata meningkat sekitar $28 \%$.

\section{Pengaruh Biaya Promosi terhadap Peningkatan Volume Penjualan Produk Wika AWH pada PT Surya Puzulindo Makassar} Corresponding Author: kartanegara@nitromks.ac.id 
Promosi merupakan salah satu faktor yang dapat mempengaruhi tingkat penjualan produk Wika AWH. Sehubungan dengan hal itu PTSurya Puzulindo Makassar berusaha mengatur kegiatan promosinya menjadi suatu program yang terpadu agar seluruh kegiatan promosi dapat menunjang tingkat penjualan produknya.

Dalam melakukan analisis menggunakan persamaan regresi sederhana terlebih dahulu disajikan data yang diperlukan dalam analisis regresi, seperti terlihat pada tabel 5.4 di bawah ini :

Tabel 5.4

Analisis Estimasi Jumlah Volume Penjualan dan jumlah Biaya promosi

Produk Wika AWH yang dikeluarkan oleh Pada PT Surya Puzulindo Makassar Periode Tahun 2004-2008

\begin{tabular}{cllllll}
\hline Tahun & $\begin{array}{c}\text { Jumlah Biaya } \\
\text { Promosi } \\
\text { X (juta) }\end{array}$ & $\begin{array}{c}\text { Jumlah volume } \\
\text { penjualan }\end{array}$ & $\begin{array}{c}\mathbf{X}^{\mathbf{2}} \\
\text { (millyar) }\end{array}$ & $\begin{array}{l}\mathbf{Y}^{\mathbf{2}} \\
\text { (trilliun) }\end{array}$ & $\begin{array}{c}\text { X.Y } \\
\text { (triliun) }\end{array}$ \\
\hline 2004 & 3,350 & $1,544,000$ & $11,222,500$ & $2,383,936,000,000$ & $5,172,400.000$ \\
2005 & 3,850 & $2,019,600$ & $14,822,500$ & $4,078,784,160,000$ & $7,775,460,000$ \\
2006 & 4,450 & $2,582,000$ & $19,802,500$ & $6,668,273,290,000$ & $11,491,235,000$ \\
2007 & 5,200 & $3,418,240$ & $27,040,000$ & $11,684,364,697,600$ & $17,774,848,000$ \\
2008 & 6,150 & $4,117,500$ & $37,822,500$ & $16,953,806,250,000$ & $25,322,625,000$ \\
Jumlah & $\mathbf{2 3 , 0 0 0}$ & $\mathbf{1 3 , 6 8 1 , 6 4 0}$ & $\mathbf{1 1 0 , 7 1 0 , 5 0 0}$ & $\mathbf{4 1 , 7 6 9 , 1 6 4 , 3 9 7 , 6 0 0}$ & $\mathbf{6 7 , 5 3 6 , 5 6 8 , 0 0 0}$ \\
\hline
\end{tabular}

Untuk mengtahui pengaruh dari biaya promosi yang dikeluarkan oleh pihak PTSurya Puzulindo terhadap volume penjualan produk Wika AWH yang dicapai, makapenulis menggunakan analisis regresi linear sederhana dengan menggunakan rumus, yaitu :

$$
\begin{aligned}
& \mathrm{Y}=\mathrm{a}+\mathrm{bx} \\
& \mathrm{b}=x=\frac{\mathrm{n} \cdot \sum \mathrm{XY}-\sum \mathrm{X} \cdot \sum \mathrm{Y}}{\mathrm{n} \sum \mathrm{X} 2-\left(\sum \mathrm{X}\right)^{2}} \\
& =\frac{5.67 .536 .568 .000-23.000 .13 .681 .640}{5.110 .710 .000-(23.000) 2} \\
& =\frac{5.67 .536 .568 .000-314.677 .720 .000}{5.110 .710 .000-529.000 .000} \\
& =\frac{337.682 .840 .000-314.677 .720 .000}{553.550 .000-529.000 .000} \\
& =\frac{23.005 .120 .000}{24.550 .000} \\
& =0,94
\end{aligned}
$$

Setelah diketahui nilai $b$, maka langkah selanjutnya adalah mencari nilai a, dengan rumus, yaitu :

$$
\begin{aligned}
\mathrm{a} \quad & =\left(\left(\sum Y-b \cdot \sum X\right) / n\right. \\
& =\frac{13.681 \cdot 640-(0,94) \cdot(23.000)}{5} \\
& =\frac{13.681 .640-21.620 .000}{5} \\
& =\frac{13.660 .120}{5} \\
& =2.732 .004
\end{aligned}
$$

Dari hasil perhitungan di atas maka diperoleh persamaan regresi sebagai berikut :

$$
\mathrm{Y}=2.732 .004+0,94 \mathrm{X}
$$

Dari persamaan diatas dapat dilihat bahwa biaya promosimempunyai hubungan yang positif dengan jumlah penjualan. Nilai-nilai dari persamaan 
regresi diatas mempunyai interprestasi sebagai berikut :

a) $b=0,94$, menunjukan bahwa naik turunnya volume penjualan dipengaruhi oleh biaya promosi. Jika biaya promosi ditambah Rp 1 maka penjualan akan meningkat sebesar $\mathrm{Rp}$ 0,94 .

b) $\mathrm{a}=2.732 .004$, menunjukan nilai konstanta, dimana apabila jumlah variabel bebas (biaya promosi) adalah nol, yang artinya tidak ada kegiatan promosi maka penjualan sebesar $\mathrm{Rp}$ 2.732.004.

c) Y, yaitu menunjukkan nilai penjualan yang berubah-ubah seiring perubahan nilai variabel bebas (X).

\section{KESIMPULAN DAN SARAN \\ Kesimpulan}

Berdasarkan hasil analisa dan uraian-uraian dalam penulisan skripsi ini, maka dapat ditarik kesimpulan dari bab hasil pembahasan sebelumnya, yaitu

1. Hasil analisis menunjukkan bahwa biaya promosi berpengaruh positif dan signifikan terhadap peningkatan volume penjualan produk Wika AWH pada PT. Surya Puzulindo Makassar. Hal ini dibuktikan dengan nilai $\mathrm{T}_{\text {hitung }}$ $>\mathrm{T}_{\text {tabel. }}$

2. Besarnya kontribusi pengaruh biaya promosi terhadap peningkatan volume penjualan produk Wika AWH pada PT. Surya Puzulindo Makassar adalah 99,4\%, sisanya dipengaruhi oleh variabel lain yang tidak diteliti yaitu $0,6 \%$.

\section{Saran}

Berdasarkan hasil pembahasan yang telah dikemukakan sebelumnya pada bab terdahulu, penulis menyampaikan saran, yaitu :

1. Kepada pihak PT Surya Puzulindo Makassar untuk lebih memperhatikan biaya promosi yang dikeluarkan, mempertahankan kualitas pemasaran, perbaikan dan penjualan yang telah melekat utuh pada setiap perusahaan, karena semakin baik pelayanan yang diberikan akan semakin besar nilai yang akan diberikan pelanggan.

2. Perlu diperhatikan sistem pelayanan pemasaran sehingga bisa menimbulkan kepuasan konsumen yang akan bertransaksi.

3. Perlu dilakukan penelitian lebih lanjut pada aspek-aspek lain yang tidak dimasukkan dalam analisa ini, mengingat masih banyak keunggulankeunggulan yang dimiliki oleh Wika AWH yang bisa dijadikan bahan untuk penelitian selanjutnya.

\section{DAFTAR PUSTAKA}

Abdul, Halim, 2000, Akutansi Biaya Bumi Aksara, Jakarta.

Angipora, P, 2002. Dasar-Dasar Pemasaran, Edisi Kedua, Cetakan Kedua, Penerbit; Raja Grafindo Persada, Jakarta.

Anthoni, 2000.Manajement Control System, Cetakan Kesembilan. Diterjamahkan oleh Herman Wibowo. Penerbit Erlangga, Jakarta.

Chandra, 2002. Strategi Program Pemasaran, Edisi Kedua, Cetakan Pertama, Penerbit; Andi Offset, Yogyakarta. 
Fandy, Tjiptono, 2002. Strategi Pemasaran, Edisi Kedua, Cetakan Keempat, Penerbit; Andi Offset, Yogyakarta

Fuad, 2005. Pengantar Bisnis, Jakarta.

Husnan, Suad, 2002, Manajemen Keuangan, Gramedia, Jakarta

Indriyo, Gitosudarmo, 2000. Manajemen Pemasaran, Edisi Pertama, Cetakan Keenam, Penerbit; BPFE, Jogjakarta

Marwan, Asri 2002, Marketing, Unit Penerbit dan Percetakan LMP2M AMPYKPN, Yogyakarta

Mulyadi, 2001, Akutansi Biaya, Erlangga, Jakarta

Prawirosentono, 2005. Manajemen Pemasaran. Edisi Millenium. Buku Kesatu. Penerbit Prehalindo, Jakarta
Philip, Kotler, 2000. Manajemen Pemasaran. Edisi Millanium, Buku I, Penerbit; Prehalindo, Jakarta.

Sofyan, Assauri, 2004. Manajemen Pemasaran, Edisi Pertama, Cetakan Ke Tujuh, Penerbit; Raja Grafindo Persada, Jakarta ,2001,

Manajemen Pemasaran, Analisis Perencanaan Implementasi dan Pengendalian, Jilid 2, Edisi Ke-6, Penerbit Erlangga, Jakarta

Swastha, DH., Basu dan Irawan, 2000. Manajemen Pamasaran Modern, Edisi Kedua, Liberty : Yogyakarta

Ronald, E., 1997. Pengantar Statistika. Edisi Ketiga, Diterjemahkan oleh Bambang Sumantri, PT. Gramedia Pustaka Utama, Jakarta. 